\title{
Autophagy suppression of trophoblast cells induces pregnancy loss by activating decidual NK cytotoxicity and inhibiting trophoblast invasion
}

Hai-Xia $\operatorname{Tan}^{1 \dagger}$, Shao-Liang Yang ${ }^{1 \dagger}$, Ming-Qing Li $i^{2,3,4^{*}}$ and Hai-Yan Wang ${ }^{1,4^{*}}$ (1)

\begin{abstract}
Background: The crosstalk between trophoblast cells and decidual NK cells plays an important role in the establishment and maintenance of normal pregnancy. Recent studies reported that autophagy can induce immune tolerance at the maternal fetal interface, while the mechanism remains unclear.

Methods: Autophagy levels in the villi of normal and recurrent spontaneous abortion (RSA) patients were detected by transmission electron microscopy. After co-cultured with trophoblast cells pretreated with 3-MA or rapamycin, NK cells were collected and the expression of killer receptors was detected by flow cytometry (FCM). The invasiveness of trophoblasts was tested by Cell invasion assay.

Results: Compared with elective pregnancy termination patients, the level of autophagy in the villi of RSA patients was significantly decreased. Inducing the autophagy level in trophoblast cells with rapamycin could significantly inhibit the cytotoxicity of NK cells in the co-culture system, and supplement of IGF-2 could rectify this effect. Meanwhile, autophagy suppression of trophoblasts reduced the level of Paternally Expressed Gene 10 (PEG10), leading to the impairment of trophoblast cell invasion. In addition, NK cells educated by autophagy-inhibited trophoblasts further decreased the proliferation and invasiveness of trophoblasts. In pregnant mice model, injection with 3-MA promoted the cytotoxicity of uterine NK cells, and increased the embryo absorption rate.

Conclusion: Autophagy suppression of trophoblasts increase the cytotoxicity of NK cells and damage the trophoblasts invasion possibly by targeting IGF-2 and PEG10, respectively, which ultimately leads to miscarriage.
\end{abstract}

Keywords: RSA, Trophoblast autophagy, NK cell, IGF-2, PEG10

\footnotetext{
*Correspondence: mqli@fudan.edu.cn; haiyanwang2002@163.com

${ }^{\dagger} \mathrm{Hai}-\mathrm{Xia}$ Tan and Shao-Liang Yang contributed equally to this work.

${ }^{2} \mathrm{NHC}$ Key Lab of Reproduction Regulation (Shanghai Institute of Planned

Parenthood Research), Hospital of Obstetrics and Gynecology, Fudan

University, Pingliang Road, Shanghai 200080, People's Republic of China

'Department of Gynecology of Integrated Traditional Chinese and Western

Medicine, Hospital of Obstetrics and Gynecology, Fudan University, Shen

Yang Road 128, Shanghai 200090, People's Republic of China

Full list of author information is available at the end of the article
}

(c) The Author(s). 2020 Open Access This article is licensed under a Creative Commons Attribution 4.0 International License, which permits use, sharing, adaptation, distribution and reproduction in any medium or format, as long as you give appropriate credit to the original author(s) and the source, provide a link to the Creative Commons licence, and indicate if changes were made. The images or other third party material in this article are included in the article's Creative Commons licence, unless indicated otherwise in a credit line to the material. If material is not included in the article's Creative Commons licence and your intended use is not permitted by statutory regulation or exceeds the permitted use, you will need to obtain permission directly from the copyright holder. To view a copy of this licence, visit http://creativecommons.org/licenses/by/4.0/. The Creative Commons Public Domain Dedication waiver (http://creativecommons.org/publicdomain/zero/1.0/) applies to the data made available in this article, unless otherwise stated in a credit line to the data. 


\section{Background}

According to the latest ESHRE guidelines, recurrent spontaneous abortion (RSA) is defined as two or more consecutive miscarriages before 24 week, occurring in about $1-2 \%$ of pregnant women [1]. The etiology of RSA is varied, mainly involving genetic factors, immune factors, endocrine dysfunction, infections, reproductive tract anatomic abnormalities, etc. [2-4]. But the cause is still unclear in a large proportion of patients. Among the patients with unknown etiology, the immune factors are of great importance [5].

Decidual natural killer cells (dNK) account for more than $70 \%$ of immune cells at fetal-maternal interface in early pregnancy [6], and they were found to perform various functions in the process of decidualization, uterine vascular remodeling and immune tolerance inducing $[7,8]$. The aberration of proportion or function of dNK cells are closely related to the occurrence of RSA. In addition, there exists cross-talk and interaction between NK cells and trophoblast cells. Trophoblasts can transmit signal to dNK cells by direct contact, or regulate NK cells function by expressing and secreting a variety of cytokines and chemokines [9-11]. In turn, it has been reported that IL-8 secreted by dNK cells plays an important role in placenta formation and trophoblast cell invasion [12]. The abnormal interaction between $\mathrm{dNK}$ and trophoblasts is associated with failure of pregnancy and abortion.

Autophagy is a catalytic process that maintains cell homeostasis in eukaryotic cells, including the degradation of damaged macromolecules and cytoplasmic components of organelles [13, 14]. Autophagy usually refers to macroautophagy, which is characterized by autophagosomes of double-membrane vesicles [15]. At present, autophagy is mainly considered as an effector and regulator of adaptive immunity, and many studies have demonstrated its role in intracellular pathogen responses [16, 17]. When cells are under hypoxia, nutrient deprivation, endoplasmic reticulum stress, mitochondrial damage, immune signals or inflammatory stimulation, autophagy was induced through various signaling pathways to maintain the normal metabolism of cells [18]. In particular, the autophagy inhibition of trophoblast induces IL$1 \beta$ secretion, thus triggering the over activated inflammatory response at the maternal-fetal interface, which may be a pathogenic mechanism of RSA induced by anti-phospholipid antibody syndrome [19]. However, the specific roles and mechanisms of autophagy in regulating the crosstalk between trophoblasts and decidual NK cells still need to be elucidated.

Trophoblast cells shares many characteristics with tumor cells in inducing and maintaining immune tolerance, especially in inducing immune tolerance of NK cells. Some researchers have found that the induction of autophagy in breast cancer cells under hypoxic conditions can effectively degrade granzyme B secreted by NK cells, thereby reducing the sensitivity of tumor cells to NK cell killing [20]. In addition, autophagy activation has been found to damage NK cell-mediated cytotoxicity in melanoma, non-small cell lung cancer and liver cancer [21-23].

Despite the fact that there exist many similarities between tumors and fetuses or allograft rejection and abortion [24], but the role of trophoblasts autophagy in maternal-fetal immune regulation remains unclear. Therefore, the aim of this study was to investigate the role of autophagy in trophoblast cells in regulating the cytotoxicity of decidual NK cells, and to explore the mechanisms of cross-talk between dNK cells and trophoblast cells in miscarriage in vitro and in vivo.

\section{Methods}

\section{Patients and samples collection}

The study protocol was approved by the Human Ethics Committee of Obstetrics and Gynecology Hospital, Fudan University, and all participants provided written informed consent. The elective pregnancy termination patients and RSA patients included in this study were at the age of 20-38 years and the gestational age was 7-9 weeks. All of them were from the Obstetrics and Gynecology Hospital of Fudan University between May 2018 and August 2019. The decidual $(n=40)$ and villi tissues $(n=14)$ were from women with normal pregnancy. Normal pregnancy patients had no history of spontaneous abortion, stillbirth and other adverse pregnancies. Blood routine and vaginal discharge tests were normal. There was no vaginal bleeding, abdominal pain, fever, pathogen infection or obvious local inflammation in all of the patients. The decidual tissues were stored in ice-cold DMEM / F-12 (HyClone, USA) under sterile conditions and transported to the lab within $1 \mathrm{~h}$ after surgery. Then, the decidual immune cells (DIC) were isolated and cultured. Villi tissues were immersed in electron microscopic fluid for subsequent test.

\section{dNK cells isolation and cell culture}

The decidual tissues were washed in PBS (HyClone), then cut into $1 \mathrm{~mm}^{3}$ pieces and digested with 20\% type IV collagenase (0.1\%; Sigma-Aldrich, USA) and 5\% DNA enzyme (3000 IU, Sigma, Germany) at $37^{\circ} \mathrm{C}$ for $30 \mathrm{~min}$. The tissue fragments were filtered through sieves (pore size: 100, 300 and 400 mesh), centrifuged at $1300 \mathrm{rpm}$ for $10 \mathrm{~min}$, and the supernatant was discarded. 20, 40, and $60 \%$ Percoll (Amersham, USA) were prepared, and then the lower layer DIC was recovered by density gradient centrifugation at $2500 \mathrm{rpm}$ for $30 \mathrm{~min}$. DIC was cultured overnight in RPMI-1640 medium (HyClone) containing $10 \%$ fetal bovine serum (FBS, Gibco, USA). 
According to the manufacturer's instructions, NK cells were negatively selected from DIC using human NK cell separation kits (MACS, Miltenyi Biotec, Germany). The dNK purity measured by FCM was over $90 \%$.

NK cells were cultured in RPMI-1640 (HyClone, USA) containing $10 \%$ FBS (Gibco) and $1 \%$ penicillinstreptomycin solution (HyClone, USA). Furthermore, IL$2(20 \mathrm{ng} / \mu \mathrm{l}), \mathrm{IL}-15(20 \mathrm{ng} / \mu \mathrm{l})$ and IGF-2 (50 ng/ $\mu \mathrm{l})$ were supplemented according to different experiments. HTR8/SVneo cell lines were cultured in DMEM/F12 (HyClone) containing 10\% FBS (Gibco) and 1\% penicillin-streptomycin solution (HyClone).

\section{Co-culture of dNK cells and HTR-8/SVneo}

HTR-8 / SVneo was pretreated with or without rapamycin $(2 \mu \mathrm{M}$, Sigma, USA) for $48 \mathrm{~h}$ in a 24 -well plate (Corning, USA) and then co-cultured with dNK cells. In addition, HTR-8 / SVneo was pretreated with or without 3-MA (10 $\mathrm{mM}$, Sigma, USA) for $24 \mathrm{~h}$ and then co-cultured with dNK cells. The ratio of dNK cells $\left(2 \times 10^{5}\right.$ cells/well $)$ to HTR-8 / SVneo $\left(1 \times 10^{5}\right.$ cells/well $)$ was $2: 1$. After $48 \mathrm{~h}$ of co-culture, all suspended cells in the co-culture system were collected for subsequent experiments.

\section{Transmission electron microscopy}

The villi of RSA patients and elective pregnancy termination patients were collected, and the tissues' volume were generally not more than $1 \mathrm{~mm}^{3}$. Fresh tissues were quickly placed into the electron microscope fixative (Servicebio), fixed at $4{ }^{\circ} \mathrm{C}$ for $2-4 \mathrm{~h}$, and post-fixed in $1 \%$ osmium acid for $2 \mathrm{~h}$. The samples were dehydrated in a series of gradient concentration alcohols, permeated overnight with a mixture of acetone and 812 embedding agent (SPI) (2:1), then embedded in pure 812 embedding agent and polymerized in a $60^{\circ} \mathrm{C}$ oven for $48 \mathrm{~h}$. Samples were cut into $60-80 \mathrm{~nm}$ ultrathin sections by using ultrathin slicing machine (Leica UC7). The sections were double stained with uranium and lead ( $2 \%$ uranyl acetate saturated alcohol solution, lead citrate) and dried overnight at room temperature. Finally, observed under a transmission electron microscope (HITACHI, HT7700), collected images for analysis.

\section{Lentiviral transfection}

HTR-8 / SVneo cells were seeded in a six-well plate $(5 \times$ $10^{4}$ cells $/ \mathrm{ml}$ ). After confluence reached $30 \%$, the cells were infected with ATG5 silencing lentivirus (ATG5RNAi)/PEG10 overexpression lentivirus (PEG10 ${ }^{\text {over }}$ ), and their corresponding negative control virus (NC) (all from Genechem Co., LTD.). According to the manufacturer's instructions, the optimal transfection condition of MOI was $80 \%$ of infected cells in the best time. Calculated the required virus volume, after $12 \mathrm{~h}$ of the cells were infected, the medium was changed and continued to culture. The transfection efficiency was observed under a fluorescence microscope at $48 \mathrm{~h}$ and $72 \mathrm{~h}$, and subsequently screened for 1 week using $1 \mu \mathrm{g} / \mathrm{ml}$ puromycin (Genechem Co., LTD.).

\section{qRT-PCR}

The cells or mouse placental tissues were collected, and total RNA was extracted by RNAiso Plus reagent (TaKaRa Biotechnology). According to the manufacturer's instructions, $1000 \mathrm{ng}$ of total RNA was reverse transcribed into cDNA with a reverse transcription kit (TaKaRa Biotechnology). Subsequently, detection was carried out on a real-time PCR instrument (ABI QuantStudio 6 Flex, USA). Reaction system $(10 \mu \mathrm{l}): 5 \mu \mathrm{TB}$ Green Premix Ex TaqTM II, $0.2 \mu \mathrm{l}$ ROX Reference Dye II, $1 \mu \mathrm{l}$ cDNA, $0.4 \mu \mathrm{l}$ Forward Primer, 0.4 $\mu$ l Reverse Primer and $3 \mu \mathrm{l}$ RNase Free $\mathrm{dH} 2 \mathrm{O}$. Primers were listed in Table 1. Reaction conditions (40 cycles): denaturation $\left(95^{\circ} \mathrm{C} 30 \mathrm{~s}\right)$, annealing $\left(95^{\circ} \mathrm{C} 5 \mathrm{~s}\right)$ and elongation $\left(60^{\circ} \mathrm{C} 34\right.$ s). Finally, the infection efficiency of lentivirus siATG5, PEG10 ${ }^{\text {over }}$ and the expression of related molecules were analyzed using the $2^{-\Delta \Delta C T}$ method.

Table 1. Related primer sequences.

\section{Transcriptome sequencing}

HTR-8/SVneo cells transfected with ATG5-RNAi $(n=3)$ and NC $(n=3)$ were added to RNAiso Plus reagent (TaKaRa), hereafter submitted to Shanghai Litzchi Biosystems (LITCHI BIO, Shanghai, China) for subsequent RNA-seq analysis. Specific processes include RNA extraction, RNA sample quality inspection, library construction, library purification, library detection, library quantification, sequencing cluster generation, and sequencing on the Hiseq 4000 platform. FastQC software (V0.10.1) was used to control the quality of the offboard data, and then DESeq2 (V1.6.3) of Bioconductor software package was used to analyze and screen the differential genes. The differentially expressed gene standards were as follows: expression amount fold difference threshold $|\log \mathrm{FC}|>1$; expression difference significance threshold $P$-value $<0.05$. The results of sequencing were analyzed and produced a related thermograms using pheatmap Version 1.0.8 in R3.4.1. In addition, based on the STRING database, the protein interaction relationship between the differential genes and the interest genes (NK function-related genes, invasion-related genes, autophagy-related genes) were predicted, and then the network maps were constructed via the Cytoscape software.

\section{Protein extraction and western blot}

After the cells were washed with PBS, lysate (RIPA: 100 XPMSF = 100:1) (Beyotime, china) was added, and the cells were separated by cell scraper after $30 \mathrm{~min}$ on ice, 
Table 1 Related primer sequences

\begin{tabular}{|c|c|c|}
\hline Genes & Primer sequences $\left(5^{\prime}-3^{\prime}\right)$ & Reverse primer $\left(5^{\prime}-3^{\prime}\right)$ \\
\hline GAPDH & $\begin{array}{l}\text { GTATCGTGGAAGGACTCA } \\
\text { TGAC }\end{array}$ & ACCACCTTCTTGATGTCATCAT \\
\hline ATG5 & $\begin{array}{l}\text { GATGGGATTGCAAAATGA } \\
\text { CAGA }\end{array}$ & GAAAGGTCTITCAGTCGTTGTC \\
\hline MAP1LC3B & $\begin{array}{l}\text { TAATTCGAGAGCAGCATC } \\
\text { CAACC }\end{array}$ & $\begin{array}{l}\text { CCGTTCACCAACAGGAAG } \\
\text { AAGG }\end{array}$ \\
\hline BECN1 & $\begin{array}{l}\text { ATCTAAGGAGCTGCCGTT } \\
\text { ATAC }\end{array}$ & $\begin{array}{l}\text { CTCCTCAGAGTTAAACTG } \\
\text { GGTT }\end{array}$ \\
\hline IL7R & $\begin{array}{l}\text { AGGCTTCTGGAGTGAATG } \\
\text { GAGTCC }\end{array}$ & $\begin{array}{l}\text { CCAAGATGACCAACAGAG } \\
\text { CGACAG }\end{array}$ \\
\hline TRIM22 & $\begin{array}{l}\text { CATCACTGCAAAGATCAAGG } \\
\text { AG }\end{array}$ & TGACCTCTITGACTCTCTCAAC \\
\hline DDIT3 & $\begin{array}{l}\text { GAGAATGAAAGGAAAGTG } \\
\text { GCAC }\end{array}$ & $\begin{array}{l}\text { ATTCACCATTCGGTCAAT } \\
\text { CAGA }\end{array}$ \\
\hline IL13RA2 & $\begin{array}{l}\text { AATTTGGAGTGAGTGGAG } \\
\text { TGAT }\end{array}$ & $\begin{array}{l}\text { CAAATGGTAGCCAGAAAC } \\
\text { GTAG }\end{array}$ \\
\hline SERPINB2 & $\begin{array}{l}\text { CCCATGACTCCAGAGAAC } \\
\text { TाA }\end{array}$ & $\begin{array}{l}\text { CTGCAAAATCGCATCAGG } \\
\text { ATAA }\end{array}$ \\
\hline MMP1 & $\begin{array}{l}\text { AGATTCTACATGCGCACA } \\
\text { AATC }\end{array}$ & $\begin{array}{l}\text { CCTITGAAAAACCGGACT } \\
\text { TCAT }\end{array}$ \\
\hline MYC & $\begin{array}{l}\text { CGACGAGACCTTCATCAA } \\
\text { AAAC }\end{array}$ & CTTCTCTGAGACGAGCTTGG \\
\hline NES & $\begin{array}{l}\text { TTGAAAAAGAGACTCAAC } \\
\text { AGCG }\end{array}$ & AAGATITTACTGCCTCTACGCT \\
\hline HAND2 & $\begin{array}{l}\text { AACTCTCCAAAATCAAGA } \\
\text { CCCT }\end{array}$ & GATTTCGTTCAGCTCCTTCTTC \\
\hline IGF2 & CTGGAGACGTACTGTGCTAC & $\begin{array}{l}\text { CATATTGGAAGAACTTGC } \\
\text { CCAC }\end{array}$ \\
\hline $\mathrm{CFH}$ & $\begin{array}{l}\text { GTGACTTACACTTGTGCA } \\
\text { ACAT }\end{array}$ & $\begin{array}{l}\text { GGGCTCCTACATTGATAA } \\
\text { CGTA }\end{array}$ \\
\hline MUC1 & $\begin{array}{l}\text { CACAGTGCTTACAGTTGT } \\
\text { TACG }\end{array}$ & TGGTCATACTCACAGCATTCTT \\
\hline CD82 & $\begin{array}{l}\text { ACAAGAGCAGTTTCATCT } \\
\text { CTGT }\end{array}$ & $\begin{array}{l}\text { CTTGCCCATGTTGAAGTAGA } \\
\text { AG }\end{array}$ \\
\hline TIMP3 & $\begin{array}{l}\text { AAGCAGATGAAGATGTAC } \\
\text { CGAG }\end{array}$ & GTACTTGTTGACCTCCAGCTTA \\
\hline PLAC8 & $\begin{array}{l}\text { TGCAGCTGATATGAATGA } \\
\text { ATGC }\end{array}$ & $\begin{array}{l}\text { TACAATGAGGACAGCAAA } \\
\text { GAGT }\end{array}$ \\
\hline PEG10 & $\begin{array}{l}\text { GATCTTCATGGAAAAGAG } \\
\text { CACC }\end{array}$ & $\begin{array}{l}\text { CATCATGAAAGCTGGGTA } \\
\text { GTTG }\end{array}$ \\
\hline
\end{tabular}

centrifuged at $12,000 \mathrm{rpm}$ for $30 \mathrm{~min}$ at $4{ }^{\circ} \mathrm{C}$. Then the supernatant was collected and the protein concentration was determined by BCA Protein Assay Kit (Beyotime, China). $1 / 4$ of $5 \times$ SDS-PAGE (Beyotime, china) was added according to the protein volume, boiled at $99{ }^{\circ} \mathrm{C}$ for $10 \mathrm{~min}$, and then store at $-80^{\circ} \mathrm{C}$. In $12.5 \% \mathrm{SDS}$ PAGE (Epizyme, Shanghai, China), the total protein (30 $\mu \mathrm{g} /$ pore) was electrophoretic and transferred to the PVDF membrane (Millipore, USA). The membrane was sealed at room temperature for $2 \mathrm{~h}$ with $5 \%$ skim milk, and then washed 3 times for $15 \mathrm{~min}$ each using TBST (Sangon Biotech). Incubated with the primary antibodies against P62 (1:1000; Cell Signaling Technology,USA), LC3B (1:1000; Cell Signaling Technology, USA), ATG5 (1:3000; Abcam, Cambridge, UK), PEG10 (1:5000; Abcam, Cambridge, UK), GAPDH (1:1000; Cell Signaling Technology,USA), $\alpha$-Tubulin (1:2000; Proteintech, USA) overnight at $4{ }^{\circ} \mathrm{C}$. Thereafter, the membranes were washed again 3 times with TBST, then incubated with horseradish peroxidase (HRP) conjugated goat-antirabbit IgG secondary antibody (1:3000; Cell Signaling Technology, USA) for $1 \mathrm{~h}$ at room temperature. Finally, the membrane was washed 3 times and subjected to chemiluminescence treatment using an ECL Detection Kit (Millipore, USA).

\section{Flow cytometry (FCM)}

dNK cells co-cultured with HTR-8 / SVneo were collected from 24-well plates and centrifuged at $1300 \mathrm{rpm}$ for $8 \mathrm{~min}$ at room. According to the recommended dose, dNK cells were stained with fluorescent dye-conjugated antibody of human antigen at $4{ }^{\circ} \mathrm{C}$ for $30 \mathrm{~min}$, including APC-conjugated anti-human CD56, FITC-conjugated anti-human CD16, APC/CY7-conjugated anti-human CD107a, PE-conjugated anti-human NKG2D/ Granzyme B, PE/CY7 -conjugated anti-human NKP30, and BV421conjugated anti-human NKP46/IFN- $\gamma$ (all from BioLegend), or the isotype control. Among them, the intracellular molecules (Granzyme B, IFN- $\gamma$ ) were added to FOXP3 Fix/Perm Buffer $(4 \times)$ (BioLegend) to fix and break the membrane, then stained with antibody for 30 min. After that, the cells were washed twice with PBS and resuspended. The samples were tested using a CyAN ADP analyzer (Beckman Coulter, USA) and analyzed by FlowJo software (TreeStar, USA). In isotype matched controls, the statistically labeled positive cells should be less than $5 \%$.

Mice NK cells were used PE-conjugated anti-mouse NK1.1, APC/Cy7-conjugated anti-mouse CD3, PerCP/Cy5.5conjugated anti-mouse CD16, FITC-conjugated anti-mouse NKG2D, APC-conjugated anti-mouse NKP46/IFN- $\gamma$, BV421conjugated anti-mouse CD107a and FITC-conjugated antihuman/mouse Granzyme B (all from BioLegend) to stain. The samples were then analyzed by flow cytometry.

\section{Immunohistochemistry}

The paraffin sections of human villi $(5 \mu \mathrm{m})$ were dehydrated in graded ethanol, next the endogenous peroxidase was removed with $3 \%$ hydrogen peroxide and incubated with $5 \%$ BSA at room temperature for $1 \mathrm{~h}$. After that, the samples were incubated with rabbit anti--human IGF-2 (1: 200; abcam); rabbit anti--human PEG10 (1:500; abcam) or rabbit IgG isotypes at $4{ }^{\circ} \mathrm{C}$ overnight. After washing with PBS for three times, the sections were incubated with HRP-labeled secondary antibody at room temperature, 
reacted with 3,3-diaminobiphenylamine (DAB), and finally counterstained with hematoxylin.

\section{Cell invasion assay}

Matrigel (BD Bioscience) was diluted at a ratio of 1:8, and $35 \mu \mathrm{L}$ was added to the transwell upper chamber ( $8 \mu \mathrm{m}$, Corning). The transwell chambers were placed in a 24-well plate for overnight stay at $4{ }^{\circ} \mathrm{C}$. $200 \mu \mathrm{l}$ (HTR-8 / SVneo, $2 \times 10^{4}$ cells/well) DMEM/F12 suspension without FBS was added to the upper chamber, and $600 \mu \mathrm{l}$ DMEM / F12 containing 10\%FBS was added to the lower chamber. According to different experimental requirements, 3-MA was added or not in the upper chamber, dNK cells $\left(1 \times 10^{5}\right.$ cells/well $)$ were added or not in the lower chamber. The cells were cultured for $48 \mathrm{~h}$ at $37^{\circ} \mathrm{C}, 5 \%$ carbon dioxide incubator. The 24-well plate was removed, and the upper chamber medium and non-penetrating cells were gently wiped off with a cotton swab, PBS washed 3 times, fixed with $4 \%$ paraformaldehyde for $30 \mathrm{~min}$, and crystal violet stained for 20 min. Thereafter, random photographs were taken under an inverted microscope $(\times 100)$, and each chamber counted 5 visual fields. The number of invaded cells was counted by ImageJ software.

\section{The cell-counting kit-8 (CCK-8) assay}

CCK-8 assay (Dojindo, Tokyo, Japan) was used to detect the proliferation ability of HTR-8/SVneo cells after coculture. The cells were seeded in 96 -well plates $\left(5 \times 10^{3}\right.$ cells/well) for $0 \mathrm{~h}, 24 \mathrm{~h}, 48 \mathrm{~h}$ and $72 \mathrm{~h}$, respectively. Then, $10 \mu$ CCK- 8 solution was added to each well and cultured for $2 \mathrm{~h}$, the absorbance value at $450 \mathrm{~nm}$ was measured by microplate reader. Six parallel holes were set for each experiment and repeated three times.

\section{In vivo experiments (mice)}

All mice used in the experiment were C57BL/6 J strain (Shanghai jiesijie experimental animal Co., Ltd.) and were raised in an SPF experimental animal facility. 8week-old female mice and 8-week-old male mice were caged at 2:1, and the pregnancy was confirmed on the day when the vaginal plug was seen ( 0.5 days). Pregnant mice were randomly divided into control group and experimental group. The experimental group was intraperitoneally injected with $3-\mathrm{MA}(100 \mathrm{mg} / \mathrm{kg} /$ time, Sigma) at day 0.5 , day 4.5 , day 10.5 , and the control group was injected with saline of equal volume at the same days. At day 8.5, the same amounts of pregnant mice in the control group and the experimental group were killed, and the number of embryo implantation and embryo absorption in the two groups were recorded respectively. The decidua cells of mice uterus were obtained by shredding, digesting, filtering and centrifuging. The relative molecular expression of NK cell was analyzed by FCM after anti-mouse immunofluorescent antibody staining. Similarly, the mice in the control group and the experimental group were randomly killed at day 14.5. In addition to recording the number of embryo implantation and embryo absorption, the endometrium of the embryo also needed to be peeled off, the development of the embryo was observed, and the crown-rump length of embryo and the weight of placenta were recorded respectively.

\section{Statistical analyses}

The results of at least three independent experiments were analyzed using the Graphpad Prism 6 (GraphPad, CA, USA) statistical software package. When the data was normally distributed, the two groups were analyzed by paired or unpaired t-test, and one-way ANOV was conducted between multiple groups. When the data was non-normally distributed, the Mann-Whitney test, the Wilcoxon test or the Kruskal-Wallis test were generally used. Data were expressed as mean \pm SEM, and considered statistically significant when $P<0.05$.

\section{Results}

The level of autophagy in trophoblasts is decreased in RSA patients

To investigate the difference of autophagy level in trophoblasts between healthy pregnant women and RSA patients, we analyzed the number and distribution of autophagosome in villi by transmission electron microscopy (Fig. 1a). As shown in the picture, the villi of RSA patients displayed fewer double-wall membranes enclosed cytoplasmic vacuoles-namely autophagosomecompared with normal pregnancy patients (Fig. 1b). What's more, the autophagosome in normal villus tissue is mainly distributed on microvillus surface, perhaps in syncytiotrophoblasts, while in RSA patients the distribution of autophagosome was in disorder. These results indicated that autophagy activity in trophoblasts was significantly lower in RSA patients compared with normal pregnant women.

\section{Autophagy in trophoblasts restricts the cytotoxicity of dNK cells}

To confirm that autophagy in trophoblasts affects the phenotype and cytotoxicity of dNK cells, dNK cells were detected by flow cytometry (FCM) after co-culturing with trophoblasts pretreated with or without rapamycin. As shown, rapamycin significantly induced the autophagy of HTR-8/SVneo cells, especially for $48 \mathrm{~h}$ (Fig. 2a). Co-culturing with rapamycin pretreated HTR-8/SVneo cells suppressed the expressions of killer receptors (CD16, NKG2D, NKP30 and NKP46) in dNK cells (Fig. 2b, c). Consistent with this, dNK cells co-cultured with autophagy-inhibiting trophoblasts expressed significantly high levels of NKG2D, NKP46 and CD107a 
a

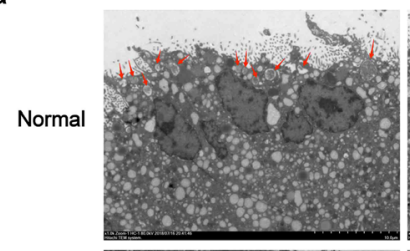

RSA

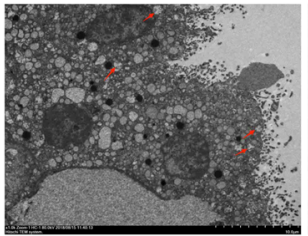

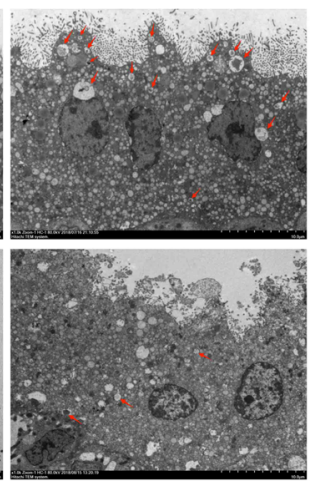

b

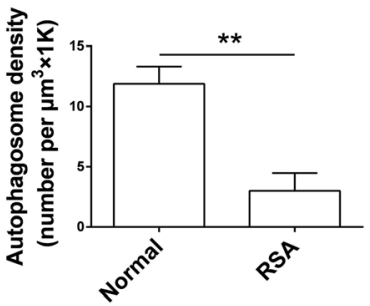

Fig. 1 The level of autophagy in trophoblasts is decreased in RSA patients. $\mathbf{a}, \mathbf{b}$ The number and distribution of autophagosomes in villi of normal women $(n=9)$ and RSA patients $(n=5)$ were detected by transmission electron microscopy. Original magnification: $\times 1.0 \mathrm{~K}$. Bar $=10 \mu \mathrm{m}$. The red arrow indicates the autophagosome. Data are expressed as the mean \pm SEM; unpaired t-test; ${ }^{* *} p<0.01$

(Fig. 2e, f), while the difference between CD16, NKP30, Granzyme B and IFN- $\gamma$ were not significant (data not shown) (Fig. 2f). These results suggest that autophagy in trophoblasts can restrict the cytotoxicity of $\mathrm{dNK}$ cells.

\section{Autophagy in trophoblasts inhibits NK cell killing activity by IGF-2}

Autophagy-related genes $(A T G)$ play a regulatory role in autophagy, and their assembled complexes are activated and recruited to the membrane to initiate autophagy. To explore how autophagy in trophoblast regulating the phenotype of dNK cells, we inhibited autophagy in trophoblasts by silencing ATG5, and then performed RNA sequencing (RNA-seq) and bioinformatics analysis. The transfection efficiency of ATG5-RNAi and the autophagy inhibiting effect was verified separately (Fig. 3a, b). As shown in the figure, there were 388 differential expressed genes, of which 210 were up-regulated and 178 were down-regulated (Fig. 3c). According to the predicted network among differential genes and NK function-related genes, we found 12 differential molecules around NCR1 (NKP46) and IFNG (IFN- $\gamma$ ) (Fig. 3d). Four up-regulated genes included TRIM22, IGF-2, CFH and $M U C 1$; and eight down-regulated genes included IL7R, DDIT3, IL13RA2, SERPINB2, MMP1, MYC, NES and HAND2. The mRNA expression of these 12 genes was verified in ATG5-silenced trophoblasts in separate experiments (Fig. 3e).

Among the 12 potential genes related to NK function, $I G F-2$ was the most significantly upregulated in ATG5RNAi group (Fig. 4a), which was also reported to be degraded by autophagy [25]. To verify whether autophagy in trophoblasts regulated the phenotype of dNK cells dependent on IGF-2, dNK cells were co-cultured with rapamycin pretreated trophoblasts, adding IGF-2 in the medium or not. As shown in the figure (Fig. 4b, c), the expression of killer receptors (CD16, NKG2D, NKP30,
NKP46, CD107a and IFN- $\gamma$ ) in rapamycin-treated group were decreased significantly, which was consistent with our previous results. Furthermore, the addition of IGF-2 could partially reverse the inhibitory effect of trophoblast autophagy on the killing activity of dNK cells. IGF-2 addition in the co-culture medium had no effect on dNK cells, which might imply that trophoblasts could secret sufficient IGF-2 in normal condition. Taken together, these data validate that autophagy in trophoblasts may suppress NK cytotoxicity by decreasing the IGF-2 secretion. And the potential pathways in which autophagy regulate the expression of IGF-2 were predicted by the bioinformatics analysis (Fig. 4d). In vivo trials further verified that the villi of RSA patients showed more IGF2 than those of normal pregnancy patients (Fig. 4e).

\section{Autophagy in trophoblasts promotes self-invasion via the PEG10}

To explore the effect of autophagy on biological behaviors of trophoblasts itself, we performed a predicted network analysis among differential genes (Fig. 3c) and trophoblast invasion-related genes. Only four overlapping molecules (TIMP3, PLAC8, CD82 and PEG10) were found (Fig. 5a). In the next verification experiment, we discovered that PLAC8, PEG10 and TIMP3 were changed in accordance with RNA-sequencing results, while CD82 was not significantly different (Fig. 5b). We further focused on PEG10 as the potential target through which autophagy might regulate the invasion in trophoblasts. PEG10 is an important imprinting gene for paternal expression and maternal imprinting. It is found to be located in 7q21, which is expressed in both adult and embryonic tissues, but is significantly expressed in the placenta [26]. It was verified that silencing ATG5 could effectively decreased the expression of PEG10 in trophoblasts (Fig. 5c), and 3-MA could also inhibit PEG10 mRNA and protein levels (Figure S1). When autophagy 


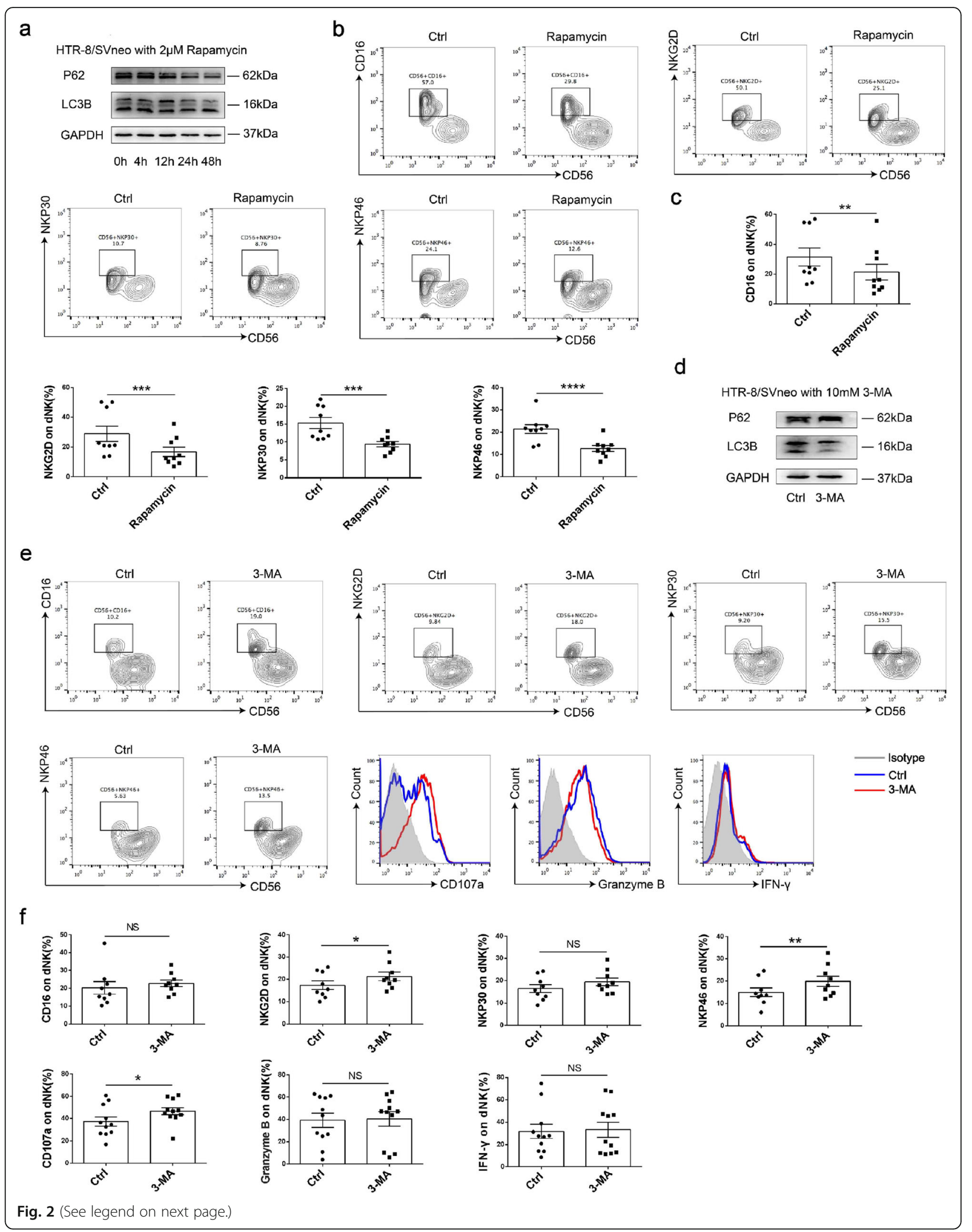


(See figure on previous page.)

Fig. 2 Autophagy in trophoblasts restricts the cytotoxicity of dNK cells. a The levels of autophagy-related proteins LC3B and P62 were detected by western blot. b, $\mathbf{c}$ HTR-8/SVneo cells were pretreated with rapamycin, then co-cultured with dNK $(n=9)$ cells for $48 \mathrm{~h}$. The expression of CD16, NKG2D, NKP30 and NKP46 in dNK cells were detected by FCM. $\mathbf{d}$ The inhibitory effect of 3-MA on autophagy was verified by western blot. e, $\mathbf{f} H T R-8 / S V n e o$ cells were pretreated with 3-MA and then co-cultured with dNK $(n=9)$ cells for $48 \mathrm{~h}$. The expression of CD16, NKG2D, NKP30, NKP46, CD107, IFN- $\gamma$ and Granzyme B in dNK cells were detected by FCM. Data are expressed as the mean \pm SEM; paired t-test or Kruskal-Wallis test; ${ }^{*} p<0.05,{ }^{* *} p<0.01,{ }^{* * *} p<$ $0.001,{ }^{* * *} p<0.0001$, NS: no significance

was inhibited by 3-MA or silencing ATG5, the invasion of HTR-8/SVneo was reduced obviously (Fig. 5d, e).

To clarify whether autophagy in trophoblasts affects self-invasion via the PEG10, we further transfected HTR8/SVneo with PEG10 overexpression lentivirus and verified the efficiency of PEG10 expression in mRNA and protein level. (Fig. 5f, g). Then, we divided HTR-8/SVneo into 4 groups: NC group, 3-MA-NC group, PEG10 ${ }^{\text {over }}$ group, 3 -MA-PEG10 ${ }^{\text {over }}$ group. The results showed that 3-MA could significantly inhibit the invasion of trophoblasts, and this effect was partly abolished by PEG10 (Fig. 5h). Actually, compared with PEG10 overexpressed group, the invasion ability was also suppressed in 3-MA-PEG10 ${ }^{\text {over }}$ group (Fig. 5i), suggesting that it may be a dual regulation loop between autophagy and PEG10, autophagy in trophoblast promotes the invasion of itself via the PEG10. To identify possible downstream signaling molecules, we found out 28 differential genes in RNA sequence

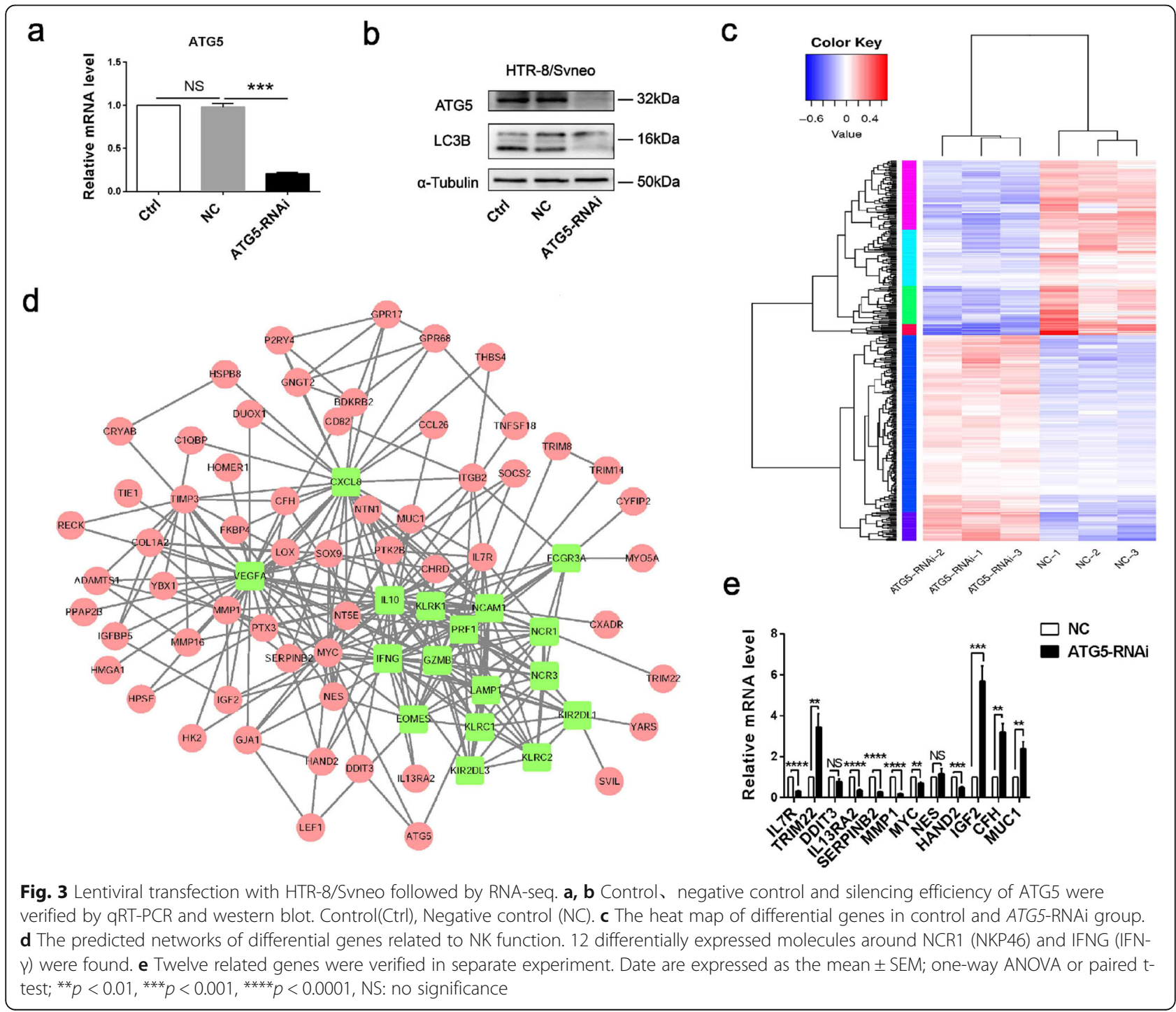




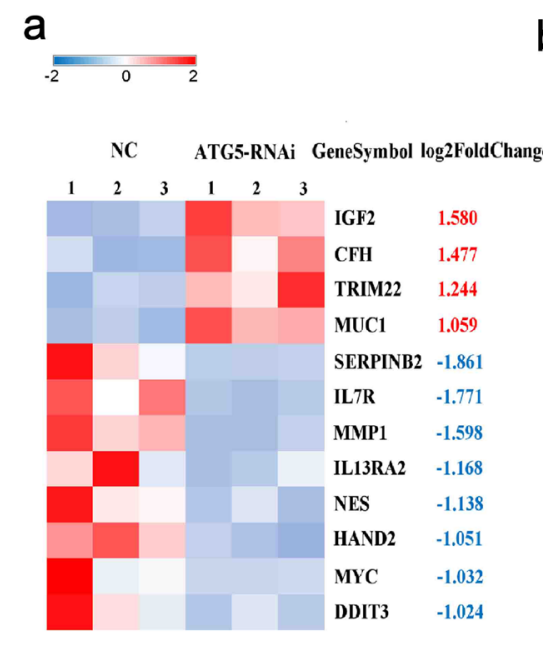

C
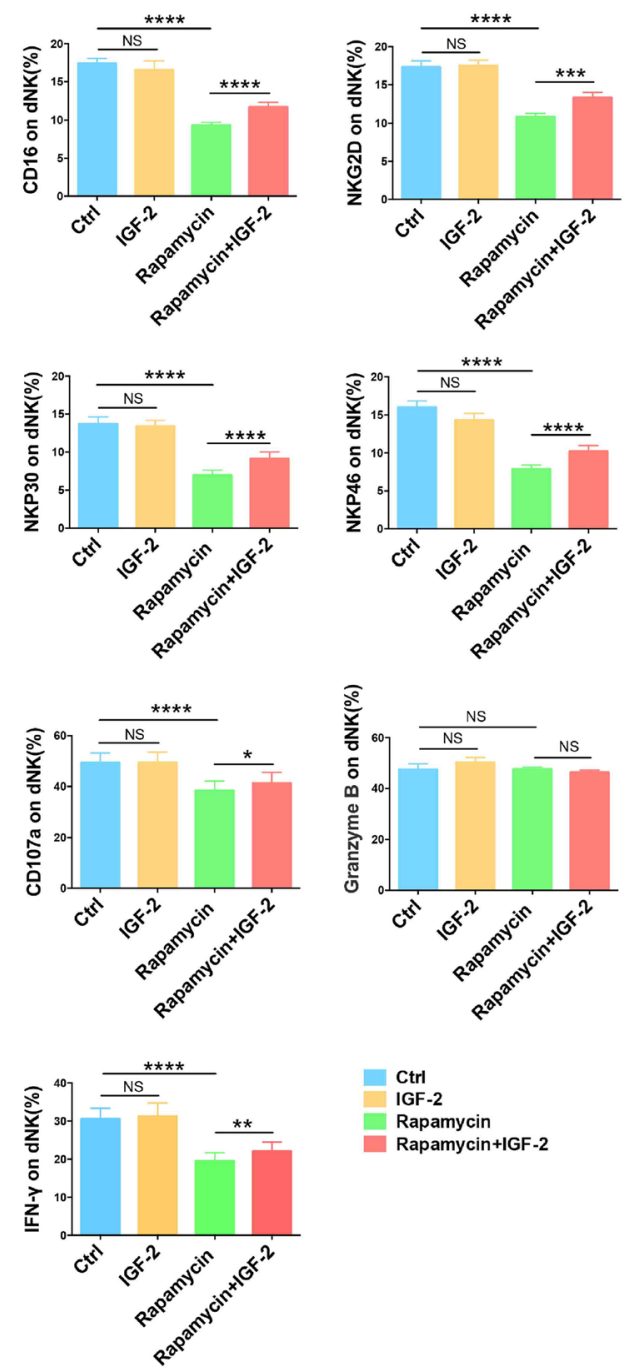
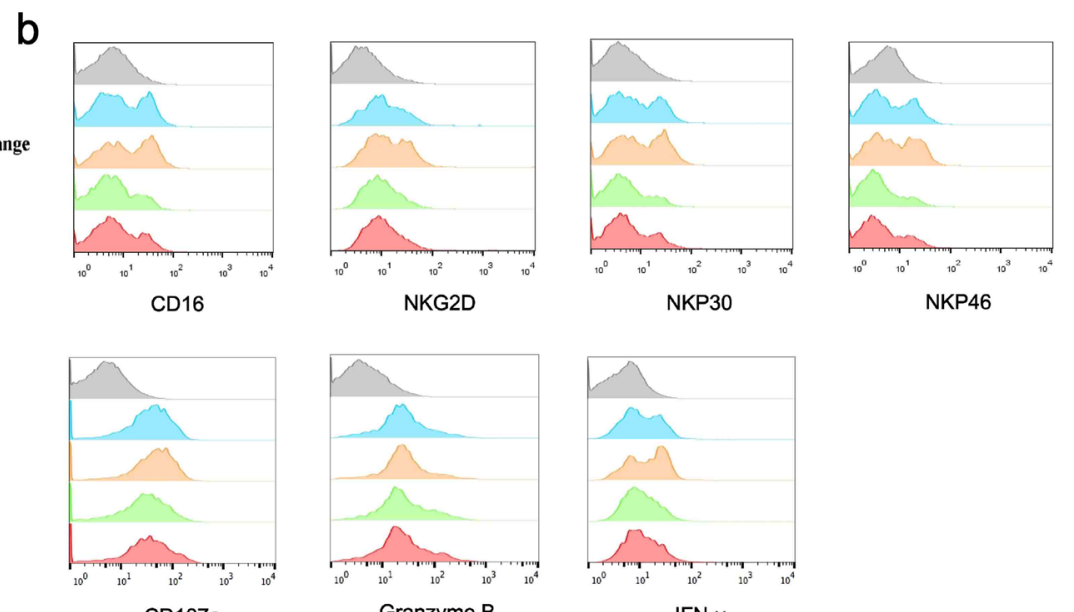

IFN-Y

d

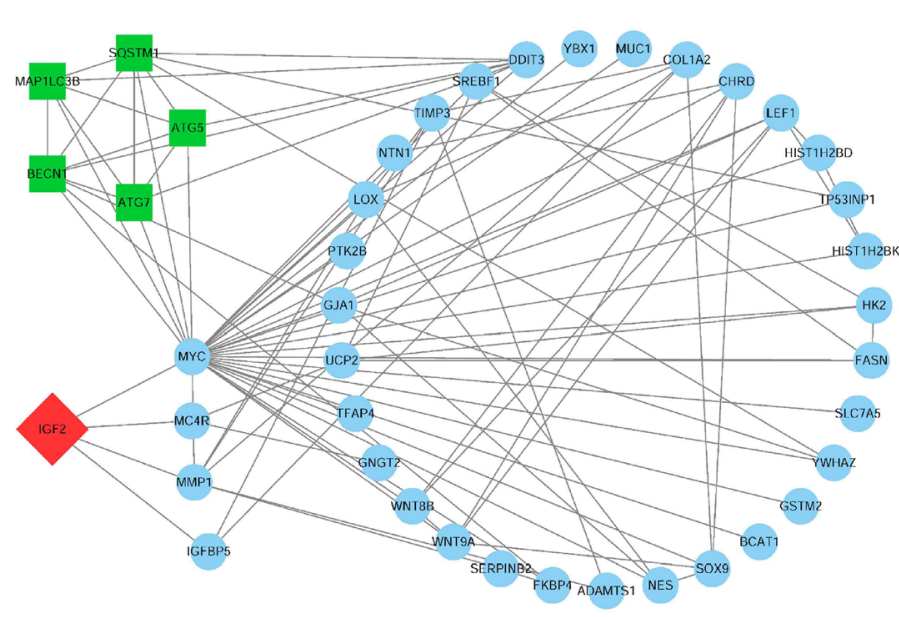

e
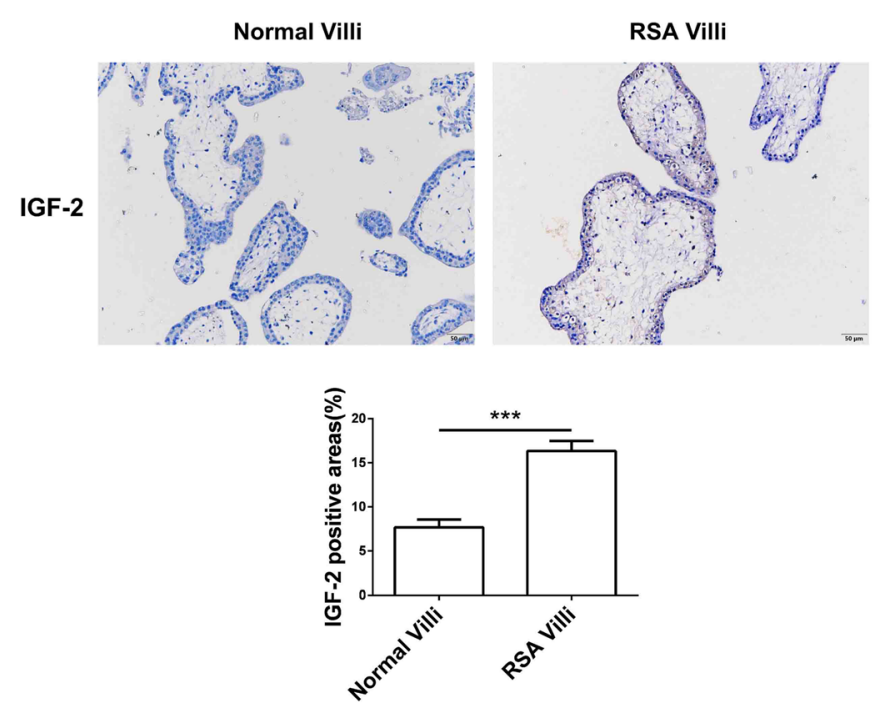

Fig. 4 (See legend on next page.) 
(See figure on previous page.)

Fig. 4 Autophagy in trophoblasts inhibits NK cell killing activity by IGF-2. a Heatmap of the differential genes associated with NCR1 and IFNG in control and ATG5-RNAi group. $\mathbf{b}, \mathbf{c}$ dNK cells $(n=6)$ were co-cultured with trophoblasts pretreated by rapamycin or solvent control, with or without IGF-2 (50 ng/ul). The expressions of killing receptors in dNK cells were detected by FCM. d. Potential molecular pathways between autophagy and IGF2 were predicted by bioinformatics analysis. e Immunohistochemistry analysis of IGF-2 expression in villi from normal pregnancy wowen ( $n=5)$ and RSA patients $(n=5)$. Original magnification: $\times 200$. The data are expressed as the mean \pm SEM; one-way ANOVA; ${ }^{*} p<0.05,{ }^{* *} p<0.01,{ }^{* * *} p<0.001$, ${ }^{* * * *} p<0.0001$, NS: no significance

associated with autophagy and PEG10, in which MYC may play a critical role (Fig. 5j). In vivo, the expression of PEG10 in villi from RSA patients were significantly lower than that villi from normal pregnancy women (Fig. 5k).

\section{dNK cell educated by autophagy-inducing trophoblasts regulates the proliferation and invasion of trophoblasts}

To explore whether dNK cells educated by trophoblasts could affect the behavior of trophoblasts in return, we collected dNK cells co-cultured with pretreated trophoblast and co-cultured them with fresh trophoblasts indirectly (Fig. 6a). The viability of pretreated-trophoblasts was detected by CCK8 after co-cultured with dNK cells. As is shown in the figure, the viability in 3-MA treated group was decreased significantly (Fig. 6b). And the invasion of trophoblasts co-cultured with dNK cells in 3MA group was also decreased (Fig. 6c, d). Taken together, we conclude that autophagy-inhibition in trophoblasts impairs the effect of dNK cells on promoting proliferation and invasion.

\section{Inhibition of autophagy in trophoblasts increases dNK cell killing activity and embryo absorption rate in vivo}

To verify the effect of trophoblasts autophagy on uterine dNK cells and embryo absorptivity in vivo, pregnant C57BL6J mice model was established. 3-MA or saline were given by intraperitoneal injection at day 0 , day 4.5 and day 10.5 of gestation. In comparison with control group, placental from 3-MA-treated pregnant mice had a low level of LC3B, proving that trophoblast autophagy was inhibited effectively in 3-MA group (Fig. 7a). The killing activity of mice uterine $\mathrm{dNK}$ cells were detected at 8.5 days of gestation. FCM results indicated that the expression of CD16, NKP46 and CD107a of dNK cells in 3-MA group were higher than the control group, but NKG2D, Granzyme B and IFN- $\gamma$ had no significant change (data not shown) (Fig. 7b). Consistently, IGF-2 was increased in the placenta of the 3-MA group (Fig. 7c).

To investigate the influence of trophoblasts autophagy inhibition on pregnancy outcome, we evaluated the abortion rate, placenta weight, and the crown-rump length of embryo at 14.5 days of gestation. No significant difference was detected in the number of implantation after 3-MA treatment, but the absorption rate in 3-MA group was increased (Fig. $7 \mathrm{~d}-\mathrm{f}$ ). And compared with the control group, the crown-rump length of embryo in the 3-MA group was decreased, while the placental weight did not change (Fig. 7g). In conclusion, our study confirms that inhibition of autophagy in trophoblast promotes the killing activity of dNK cells and increases fetal loss in mice.

\section{Discussion}

Autophagy is a non-apoptotic form of over-activated programmed cell death [27, 28]. During the process of autophagy, both autophagy-related genes (ATG) and microtubule-associated protein 1 light chain 3 (MAP1LC3, commonly known as LC3) are involved in the development and maturation of autophagosome. Especially, ATG5 participates in the formation of the complex ATG12-ATG16L1, and then recruits LC3 on the phage membrane and promotes the processing of LC3 [29, 30]. Autophagy plays an indispensable role in early embryonic development, which is often associated with abortion, preeclampsia, intrauterine growth restriction [31-33]. In this study, we found that the level of autophagy in villi of RSA patients was significantly lower than that of elective pregnancy termination patients. Here, we demonstrate that the reduction of autophagy in trophoblasts increases the killing activity of dNK cells through IGF-2, and impairs PEG10-mediated trophoblasts invasion.

IGF-2 is a multifunctional cell proliferation regulation factor, which plays an important role in cell differentiation, embryo growth and development, and tumor cell proliferation [34, 35]. The effect of IGF-2 is mainly mediated by the insulin receptor (IR); type1 IGF receptor (IGF-1R); type2 IGF receptor (IGF-2R) [36]. For example, the binding of IGF- 2 and IGF-1R can activate the tyrosine kinase domain, triggering mitogen-activated protein kinase (MAPK)/extracellular signal-regulated kinases (ERK) and phosphoinositide 3-kinase (PI3K)/AKT (protein kinase B) to promote anti-apoptotic effect, which in turn triggers the effect on cell proliferation by the mammalian target of rapamycin (mTOR) pathway $[37,38]$. At present, little is known about the regulatory effect of IGF-2 on NK cell function. IGF-2 may regulate the killing effect of NK cells through the START3 (signal transducer and activator of transcription 3) signaling pathway. Our previous research has found that the signal START3 plays an important role in NK cytotoxicity or 


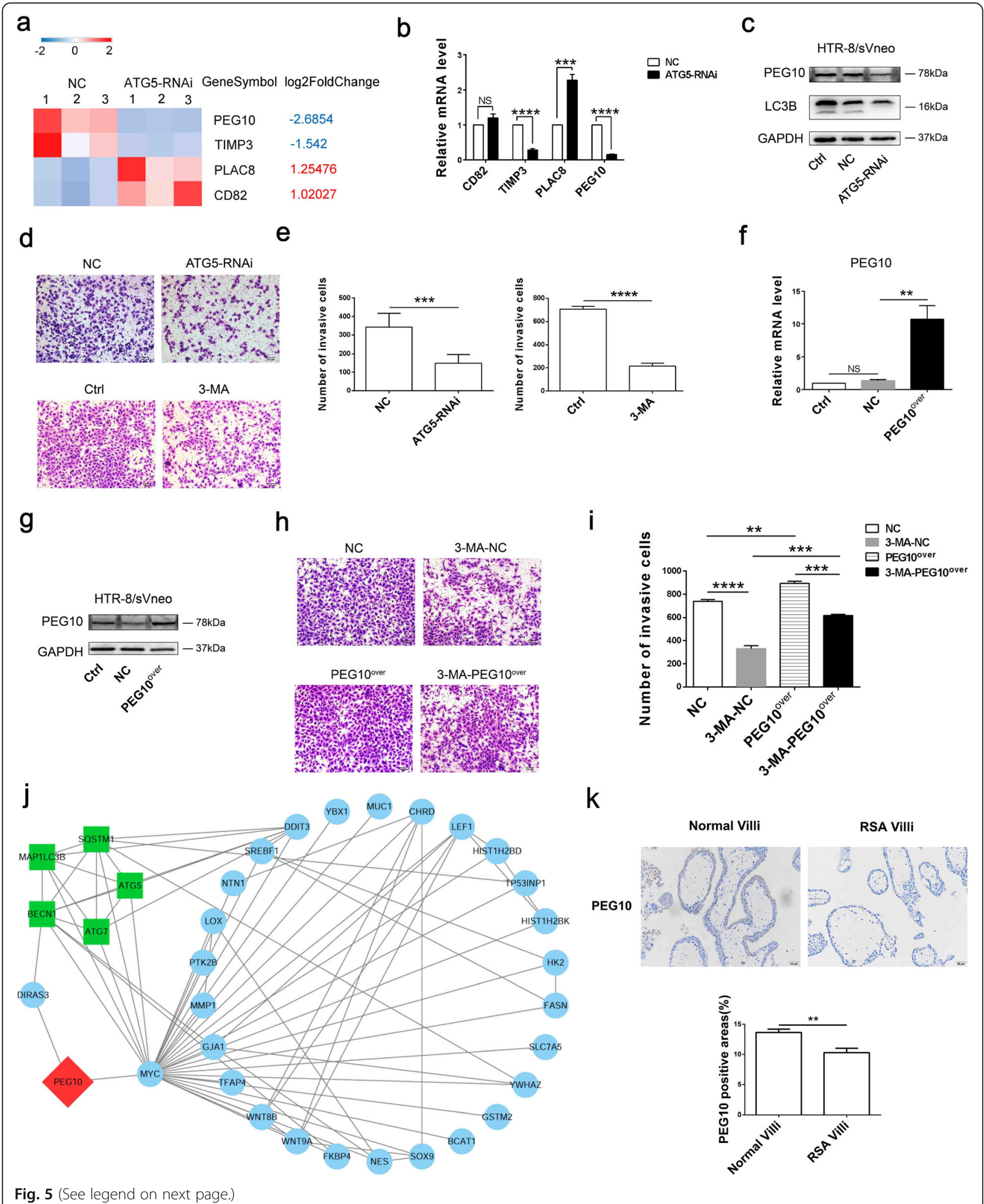

functional regulation [11]. IGF-2, which is present in tumor cells, can be secreted by activated STAT3 to impair the antitumor efficacy of anti-IGF-2 therapy [39].
Therefore, we speculate that IGF-2 may affect NK cell killing activity in an indirect way. In our current research, we found that IGF-2 could be induced by 
(See figure on previous page.)

Fig. 5 Autophagy in trophoblast promotes the invasion of itself via the PEG10. a Heatmap of the differential genes associated with trophoblast invasion in control and ATG5-RNAi group. $\mathbf{b}$ The four screened genes were identified by qRT-PCR. c PEG10 expression was verified by western blot. $\mathbf{d}$, e The invasion of trophoblasts that transfected with negative control lentivirus, ATG5 silencing virus, treated with 3-MA or control was detected by transwell assay. Scale bar: $100 \mu \mathrm{m}$. f, g PEG10 expression levels in trophoblast transfected with PEG10 overexpression lentivirus, negative control lentivirus or the control group were verified by western blot and qRT-PCR. $\mathbf{h}$, $\mathbf{i}$ The invasion of trophoblasts in NC group, 3-MANC group, PEG10 over group, 3-MA-PEG10 ${ }^{\text {over }}$ group was detected by transwell assay. Scale bar: $100 \mu \mathrm{m}$. $\mathbf{j}$ Potential molecular pathways between autophagy and PEG10 were predicted by bioinformatics analysis. $\mathbf{k}$ PEG10 expression in villi of normal pregnancy women $(n=5)$ and RSA parients $(n=5)$ by immunohistochemistry. Original magnification: $\times 200$. The data are expressed as the mean \pm SEM; one-way ANOVA, paired ttest; ${ }^{*} p<0.05,{ }^{* *} p<0.01,{ }^{* * *} p<0.001,{ }^{* * *} p<0.0001$, NS: no significance

autophagy-inhibited trophoblast cells. And whether autophagy in trophoblast cells regulates NK cell killing activity by IGF-2 should to be further studied.

After co-cultured with 3-MA-pretreated HTR-8/ SVneo cells, the killing activity of $\mathrm{dNK}$ cells was increased significantly. Similar results were obtained in vivo. Interestingly, supplementation with IGF-2 partially reversed the effect of autophagy in trophoblast cells on the killing receptor of NK cells, suggesting that trophoblasts autophagy inhibits NK cell killing activity by IGF-2. In fact, the specific regulation of IGF-2 by trophoblasts autophagy is largely unknown. Although this study was the first to discover that autophagy in trophoblast cells could regulate NK cell cytotoxicity through IGF-2, we were unable to further validate it in vivo due to the lack of ATG5 knockout mice. Fortunately, the protein interaction between IGF-2 and autophagy-related genes were analyzed based on our sequencing results. It was found that autophagy-related genes were associated with IGF-2 through 35 differential genes. This provides a reliable basis for the next experiments. a

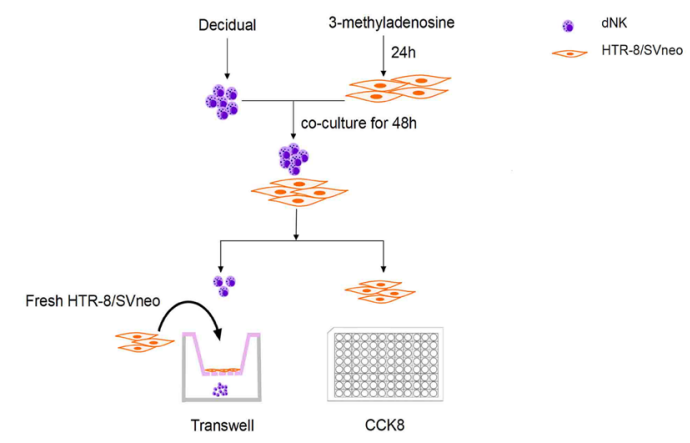

C
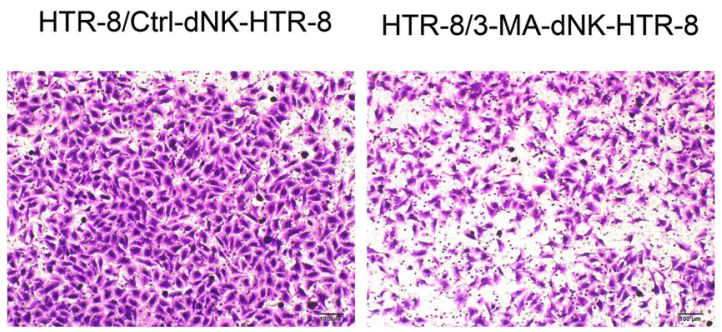

b

HTR-8/SVneo

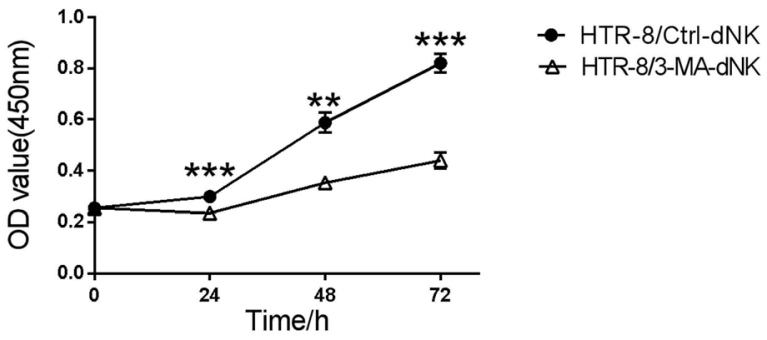

d

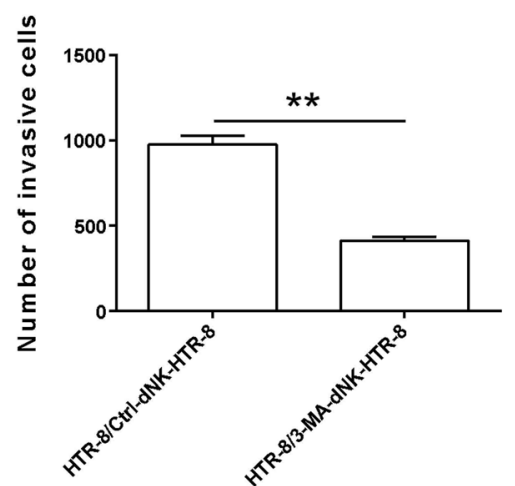

Fig. 6 dNK cell educated by autophagy-inducing trophoblasts affects the proliferation and invasion of trophoblasts. a Schematic process of cell treatment. dNK cells were co-cultured with 3-MA treated trophoblast for $48 \mathrm{~h}$. Then, the trophoblasts were collected to detect the viability by CCK8 and the dNK cells were collected to co-culture with fresh trophoblasts indirectly. The invasion of these fresh trophoblasts was measured by transwell assay. $\mathbf{b}$. Cell viability of trophoblasts was detected by CCK8. $\mathbf{c}$, $\mathbf{d}$ The invasion of trophoblasts was detected by transwell assay. Scale bar: $100 \mu \mathrm{m}$. The data are expressed as the mean \pm SEM; paired t-test; ${ }^{* *} p<0.01 ;{ }^{* * *} \mathrm{p}<0.001$ 


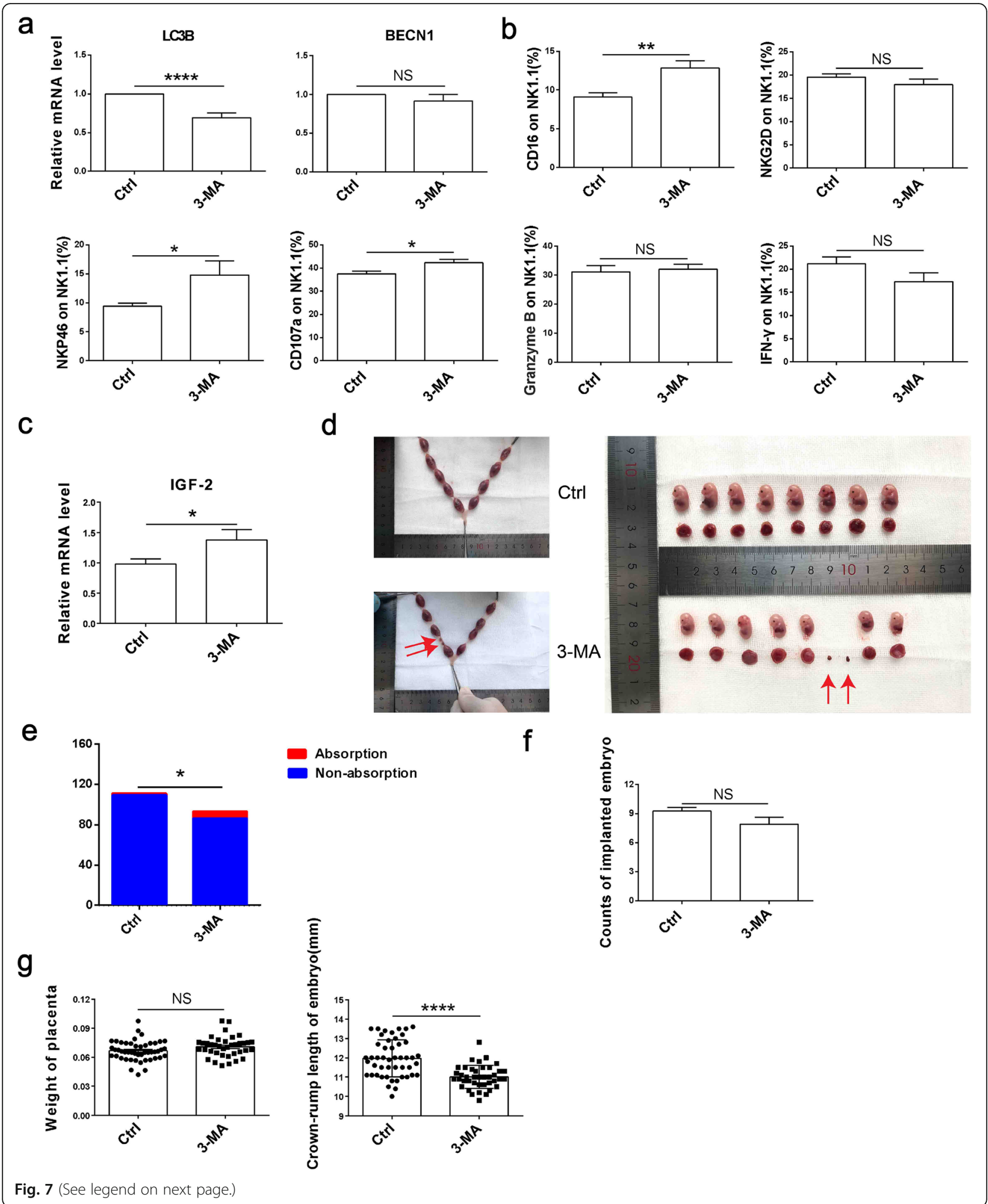

In addition, autophagy is also associated with cell invasion. We confirmed that 3-MA caused a significant reduction of invasiveness in trophoblast cells, which is consistent with previous research findings [40]. According to bioinformatics analysis, we found the most different gene PEG10. As reported, PEG10 promotes trophoblasts 
(See figure on previous page.)

Fig. 7 Inhibition of trophoblasts autophagy increases dNK cell killing activity and embryo absorption rate in vivo. a The mRNA expression of autophagy-associated molecules (LC3B, Beclin) was detected by qRT-PCR in placental. $\mathbf{b}$ At 8.5 days of pregnancy, the expression of NK killer receptors in the uterus were detected by FCM (Ctrl, $n=6,3-M A, n=6)$. c The mRNA expression of IGF-2 in placenta of mice was detected by qRT-PCR (Ctrl, $n=6 ; 3-M A, n=6)$. d, e Embryo absorption rate of control group and 3-MA group (Ctrl, $n=12 ; 3-M A, n=11)$. f The number of embryo implantations (Ctrl, $n=12 ; 3-M A, n=12)$. $g$ The weight of placenta and the embryo crown-rump length in both groups $(C t r l, n=6 ; 3-M A$, $n=6$ ). The data are expressed as the mean \pm SEM; unpaired t-test, Mann-Whitney, Chi-square test; ${ }^{*} p<0.05,{ }^{* *} p<0.01$, ${ }^{* * *} p<0.001,{ }^{* * *} p<$ 0.0001, NS: no significance

invasion by TIMP-1, and PEG-10 knockout may cause placental defects and early embryonic lethality in mice $[41,42]$. This suggests that the decrease of PEG10 gene may be a cause of recurrent abortion. PEG10 is also considered as a cancer imprinting gene. Several scholars have pointed out that E2F1-mediated PEG10 overexpression can promote the proliferation, invasion and migration of tumor cells (pancreatic cancer, liver cancer and prostate cancer, etc.) [43-45]. Li et al. demonstrate that curcumin inhibits SIAH1-mediated apoptosis via the miR-491/ PEG10 pathway, leading to stagnant cancer cell growth [46]. In this study, our findings indicate that autophagy inhibition decreased the level of PEG-10 in trophoblast cells. Subsequently, we validated that autophagy could positively regulate the invasive function of trophoblast cells via the PEG10. Unfortunately, the regulatory mechanism between trophoblasts autophagy and PEG10 in this experiment has not been deeply involved, and we can further study it based on existing clues.

There is a correlation between HTR-8/SVneo and educated dNK. Cichocki et al have reported that there is a clear immunological memory characteristic of mature natural killer cells in response to chronic human cytomegalovirus (HCMV) [47]. Ghofrani et al revealed that "memory" NK cells can also be induced by cytokines (such as IL-12, IL-15 and IL-18, [48]). Gamliel et al. disclosed that is mainly restricted to NKG2Chi decidua "memory" NK cells (called PTdNKs), high expression receptors NKG2C and LILRB1, supporting repeated pregnancy [49]. Unlike HCMV and cytokine-induced "memory" NK cells, PTdNKs not only secrete high amounts of IFN- $\gamma$, but also uniquely exhibit higher secretion of VEGF $\alpha$, promoting angiogenesis and decidua maintenance at implantation sites. In this research, it is confirmed that there is a negative feedback regulation loop between the HTR-8/SVneo and educated dNK. Based on the above evidence, dNK cell educated by autophagy-inducing trophoblasts may have the different secretion of cytokines, which may further affect the invasion ability of trophoblasts,

However, the regulation mechanism of "memory" NK cells require further work.

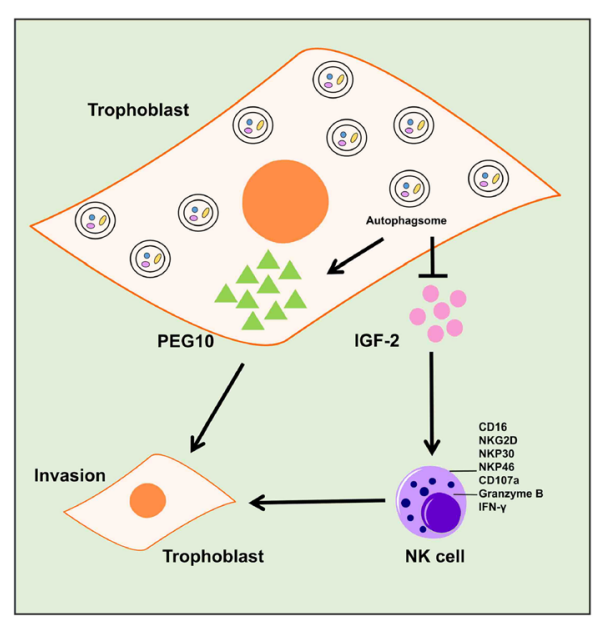

Normal pregnancy

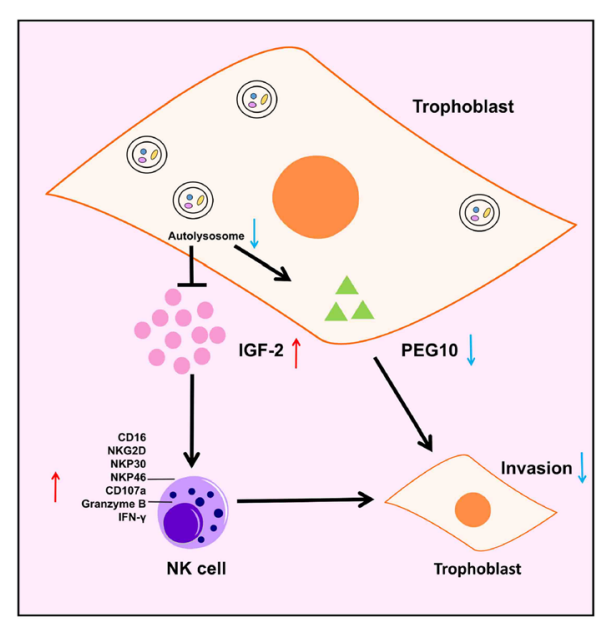

RSA

Fig. 8 Schematic roles of trophoblasts autophagy on dNK cytotoxicity and trophoblast invasion in early pregnancy. Autophagy in trophoblast cell is decreased in RSA patients. On the one hand, low level of autophagy in trophoblast leads to the increase of IGF-2 secretion, which further leads to the high killing activity of NK cells attacking the normal cells; on the other hand, autophagy suppression of trophoblast cells decreases the PEG10, which reduces the invasion of trophoblasts. In addition, dNK cells educated by trophoblasts can affect the behavior of trophoblasts in return. Autophagy depression in trophoblast suppresses the effect of dNK cells on promoting proliferation and invasion. As a result, the impairment of autophagy in trophoblast may leads to recurrent spontaneous abortion 


\section{Conclusions}

Collectively, as shown (Fig. 8), we have demonstrated that autophagy suppression of trophoblast cells induces RSA through IGF-2 secretion and PEG10 reduction. On the one hand, high levels of IGF-2 leads to NK cells differentiation, and these NK cells with high killing activity attacked normal cells at the maternal-fetal interface. On the other hand, autophagy suppression of trophoblast cells decreases the PEG10, which reduces the invasive function of trophoblasts and leads to pregnancy maintain failure. In addition, dysfunctional "memory" NK cells in the first pregnancy will continue to affect newly formed trophoblasts, and these processes will form a vicious positive feedback cycle that will ultimately accelerate the progression of RSA. Based on this research, future RSA treatments can be combined with autophagy inducers. Previous reports have suggested the idea of targeted autophagy for cancer treatment [50]. For example, rapamycin is both an immunosuppressant and an autophagy inducer. It may have therapeutic value for immune abortion with low level of autophagy in trophoblast. Simultaneously, IGF-2 inhibitors can alleviate the NK cell toxicity mediated by IGF-2, and have potential value in the treatment of diseases associated with NK cytotoxicity.

\section{Supplementary information}

Supplementary information accompanies this paper at https://doi.org/10. 1186/s12964-020-00579-w.

Video Abstarct

Additional file 1: Supplementary Figure 1. 3-MA treatment of HTR-8/ SVneo decreases the expression of PEG10. a,b After HTR-8/SVneo was treated with 3-MA, the MRNA and protein levels of PEG10 were detected. The data are expressed as the mean \pm SEM; paired t-test; ${ }^{*} p<0.05$.

\section{Abbreviations}

dNK: Decidual natural killer cells; RSA: Recurrent spontaneous abortion; 3MA: 3-Methyladenosine; IGF-2: Insulin-like growth factor-2; PEG10: Paternally Expressed Gene 10; CCK-8: Cell-counting kit-8; FCM: Flow cytometry; DIC: Decidual immune cell; ATG: Autophagy-related genes;

MAP1LC3: Microtubule-associated protein 1 light chain 3; MAPK: Mitogenactivated protein kinase; ERK: Extracellular signal-regulated kinases;

PI3K: Phosphoinositide 3-kinase; START3: Signal transducer and activator of transcription 3; mTOR: Mammalian target of rapamycin

\section{Acknowledgments}

There are no acknowledgements.

\section{Authors' contributions}

Hai-Xia Tan performed all experiments and edited the manuscript. ShaoLiang Yang assisted in vivo and vitro trials. Ming-Qing Li and Hai-Yan Wang designed the study, supervised the experiment project. All authors read and approved the final manuscript.

\section{Funding}

This research was supported by the National Natural Science Foundation of China (NSFC) (No. 31970798, 31671200, 81373868) and the NPFPC Key Laboratory of Reproductive Regulations (CX2017-2).

\section{Availability of data and materials}

The datasets involved in our study are available on reasonable request.

\section{Ethics approval and consent to participate}

The study protocol was approved by the Human Ethics Committee of the Fudan University Obstetrics and Gynecology Hospital (Ethics 2018-70).

\section{Consent for publication}

All authors agree to publish.

\section{Competing interests}

The authors declare that there is no potential conflict of interest.

\section{Author details}

${ }^{1}$ Department of Gynecology of Integrated Traditional Chinese and Western Medicine, Hospital of Obstetrics and Gynecology, Fudan University, Shen Yang Road 128, Shanghai 200090, People's Republic of China. ${ }^{2} \mathrm{NHC}$ Key Lab of Reproduction Regulation (Shanghai Institute of Planned Parenthood Research), Hospital of Obstetrics and Gynecology, Fudan University, Pingliang Road, Shanghai 200080, People's Republic of China. ${ }^{3}$ Laboratory for Reproductive Immunology, Hospital of Obstetrics and Gynecology, Fudan University, Shanghai 200080, People's Republic of China. ${ }^{4}$ Shanghai Key Laboratory of Female Reproductive Endocrine Related Diseases, Shanghai 200080, People's Republic of China.

Received: 6 December 2019 Accepted: 13 April 2020

Published online: 12 May 2020

\section{References}

1. Bender AR, Christiansen OB, Elson J, Kolte AM, Lewis S, Middeldorp S, Nelen W, Peramo B, Quenby S, Vermeulen N, Goddijn M. ESHRE guideline: recurrent pregnancy loss. Hum Reprod Open. 2018;2018:y4.

2. Baek KH, Lee EJ, Kim YS. Recurrent pregnancy loss: the key potential mechanisms. Trends Mol Med. 2007:13:310-7.

3. Colley E, Hamilton S, Smith P, Morgan NV, Coomarasamy A, Allen S. Potential genetic causes of miscarriage in euploid pregnancies: a systematic review. Hum Reprod Update. 2019;25:452-72.

4. Larsen EC, Christiansen OB, Kolte AM, Macklon N. New insights into mechanisms behind miscarriage. BMC Med. 2013;11:154.

5. Deshmukh H, Way SS. Immunological basis for recurrent fetal loss and pregnancy complications. Annu Rev Pathol. 2019;14:185-210.

6. Bulmer JN, Morrison L, Longfellow M, Ritson A, Pace D. Granulated lymphocytes in human endometrium: histochemical and immunohistochemical studies. Hum Reprod. 1991;6:791-8.

7. Moffett-King A. Natural killer cells and pregnancy. Nat Rev Immunol. 2002;2: 656-63.

8. Vacca P, Vitale C, Munari E, Cassatella MA, Mingari MC, Moretta L. Human innate lymphoid cells: their functional and cellular interactions in decidua. Front Immunol. 2018;9:1897.

9. Ban Y, Zhao Y, Liu F, Dong B, Kong B, Qu X. Effect of Indoleamine 2,3Dioxygenase expressed in HTR-8/SVneo cells on Decidual NK cell cytotoxicity. Am J Reprod Immunol. 2016;75:519-28.

10. Wang XQ, Zhou WJ, Hou XX, Fu Q, Li DJ. Trophoblast-derived CXCL16 induces M2 macrophage polarization that in turn inactivates NK cells at the maternal-fetal interface. Cell Mol Immunol. 2018;15:1038-46.

11. Mei J, Zhou WJ, Zhu XY, Lu H, Wu K, Yang HL, Fu Q, Wei CY, Chang KK, Jin $L P$, et al. Suppression of autophagy and HCK signaling promotes PTGS2(high) FCGR3(-) NK cell differentiation triggered by ectopic endometrial stromal cells. Autophagy. 2018;14:1376-97.

12. Sharma S, Godbole G, Modi D. Decidual control of Trophoblast invasion. Am J Reprod Immunol. 2016;75:341-50.

13. Levine B, Klionsky DJ. Development by self-digestion: molecular mechanisms and biological functions of autophagy. Dev Cell. 2004;6:463-77.

14. Chun Y, Kim J. Autophagy: an essential degradation program for cellular homeostasis and life. Cells-Basel. 2018;7.

15. Galluzzi L, Baehrecke EH, Ballabio A, Boya P, Bravo-San PJ, Cecconi F, Choi AM, Chu CT, Codogno P, Colombo Ml, et al. Molecular definitions of autophagy and related processes. EMBO J. 2017;36:1811-36.

16. Choi Y, Bowman JW, Jung JU. Autophagy during viral infection - a doubleedged sword. Nat Rev Microbiol. 2018;16:341-54. 
17. Evans RJ, Sundaramurthy V, Frickel EM. The interplay of host autophagy and eukaryotic pathogens. Front Cell Dev Biol. 2018;6:118.

18. Ravanan P, Srikumar IF, Talwar P. Autophagy: the spotlight for cellular stress responses. Life Sci. 2017;188:53-67.

19. Mulla MJ, Weel IC, Potter JA, Gysler SM, Salmon JE, Peracoli M, Rothlin CV, Chamley LW, Abrahams VM. Antiphospholipid antibodies inhibit Trophoblast toll-like receptor and Inflammasome negative regulators. Arthritis Rheumatol. 2018;70:891-902.

20. Baginska J, Viry E, Berchem G, Poli A, Noman MZ, van Moer K, Medves S, Zimmer J, Oudin A, Niclou SP, et al. Granzyme B degradation by autophagy decreases tumor cell susceptibility to natural killer-mediated lysis under hypoxia. Proc Natl Acad Sci U S A. 2013;110:17450-5.

21. Tittarelli A, Janji B, Van Moer K, Noman MZ, Chouaib S. The selective degradation of synaptic Connexin 43 protein by hypoxia-induced autophagy impairs natural killer cell-mediated tumor cell killing. J Biol Chem. 2015;290:23670-9.

22. Yao C, Ni Z, Gong C, Zhu X, Wang L, Xu Z, Zhou C, Li S, Zhou W, Zou C Zhu S. Rocaglamide enhances NK cell-mediated killing of non-small cell lung cancer cells by inhibiting autophagy. Autophagy. 2018;14:1831-44.

23. Zhao H, Jia H, Han Q, Zhang J. Homeobox containing 1 inhibits liver cancer progression by promoting autophagy as well as inhibiting stemness and immune escape. Oncol Rep. 2018;40:1657-65.

24. Beaman KD, Dambaeva S, Katara GK, Kulshrestha A, Gilman-Sachs A. The immune response in pregnancy and in cancer is active and supportive of placental and tumor cell growth not their destruction. Gynecol Oncol. 2017; 145:476-80.

25. Pereira SS, Monteiro MP, Costa MM, Moreira A, Alves MG, Oliveira PF, Jarak I, Pignatelli D. IGF2 role in adrenocortical carcinoma biology. Endocrine. 2019; 66:326-37.

26. Ono R, Kobayashi S, Wagatsuma H, Aisaka K, Kohda T, Kaneko-Ishino T, Ishino F. A retrotransposon-derived gene, PEG10, is a novel imprinted gene located on human chromosome 7q21. Genomics. 2001;73:232-7.

27. Kroemer G, Galluzzi L, Vandenabeele P, Abrams J, Alnemri ES, Baehrecke EH, Blagosklonny MV, El-Deiry WS, Golstein P, Green DR, et al. Classification of cell death: recommendations of the nomenclature committee on cell death 2009. Cell Death Differ. 2009:16:3-11.

28. Fulda S, Kogel D. Cell death by autophagy: emerging molecular mechanisms and implications for cancer therapy. Oncogene. 2015;34:5105-13.

29. Kim KH, Lee MS. Autophagy--a key player in cellular and body metabolism. Nat Rev Endocrinol. 2014:10:322-37.

30. Perez-Hernandez M, Arias A, Martinez-Garcia D, Perez-Tomas R, Quesada R, Soto-Cerrato V. Targeting autophagy for Cancer treatment and tumor Chemosensitization. Cancers (Basel). 2019;11.

31. Cao B, Camden AJ, Parnell LA, Mysorekar IU. Autophagy regulation of physiological and pathological processes in the female reproductive tract. Am J Reprod Immunol. 2017;77.

32. Xu Y, Huang X, Xie J, Chen Y, Fu J, Wang L. Let-7i-induced Atg4B suppression is essential for autophagy of placental Trophoblast in preeclampsia. J Cell Physiol. 2017;232:2581-9.

33. Nakashima A, Tsuda S, Kusabiraki T, Aoki A, Ushijima A, Shima T, Cheng SB, Sharma S, Saito S. Current understanding of autophagy in pregnancy. Int J Mol Sci. 2019;20.

34. Livingstone C. IGF2 and cancer. Endocr Relat Cancer. 2013:20:R321-39.

35. White V, Jawerbaum A, Mazzucco MB, Gauster M, Desoye G, Hiden U. IGF2 stimulates fetal growth in a sex- and organ-dependent manner. Pediatr Res. 2018;83:183-9

36. Yu H, Rohan $\mathrm{T}$. Role of the insulin-like growth factor family in cancer development and progression. J Natl Cancer Inst. 2000;92:1472-89.

37. Ribeiro TC, Latronico AC. Insulin-like growth factor system on adrenocortical tumorigenesis. Mol Cell Endocrinol. 2012;351:96-100

38. Wang MJ, Chen F, Liu QG, Liu CC, Yao H, Yu B, Zhang HB, Yan HX, Ye Y, Chen $T$, et al. Insulin-like growth factor 2 is a key mitogen driving liver repopulation in mice. Cell Death Dis. 2018;9:26.

39. Lee JS, Kang JH, Boo HJ, Hwang SJ, Hong S, Lee SC, Park YJ, Chung TM, Youn H, Mi LS, et al. STAT3-mediated IGF-2 secretion in the tumour microenvironment elicits innate resistance to anti-IGF-1R antibody. Nat Commun. 2015;6:8499

40. Ito S, Koshikawa N, Mochizuki S, Takenaga K. 3-Methyladenine suppresses cell migration and invasion of HT1080 fibrosarcoma cells through inhibiting phosphoinositide 3-kinases independently of autophagy inhibition. Int J Oncol. 2007;31:261-8.
41. Ono R, Nakamura K, Inoue K, Naruse M, Usami T, Wakisaka-Saito N, Hino T, Suzuki-Migishima R, Ogonuki N, Miki H, et al. Deletion of Peg10, an imprinted gene acquired from a retrotransposon, causes early embryonic lethality. Nat Genet. 2006;38:101-6.

42. Chen H, Sun M, Liu J, Tong C, Meng T. Silencing of paternally expressed gene 10 inhibits Trophoblast proliferation and invasion. PLoS One. 2015;10: e144845.

43. Peng YP, Zhu Y, Yin LD, Zhang JJ, Wei JS, Liu X, Liu XC, Gao WT, Jiang KR, Miao Y. PEG10 overexpression induced by E2F-1 promotes cell proliferation, migration, and invasion in pancreatic cancer. J Exp Clin Cancer Res. 2017;36:30.

44. Wang D, Zhao J, Li S, Wei J, Nan L, Mallampalli RK, Weathington NM, Ma H, Zhao Y. Phosphorylated E2F1 is stabilized by nuclear USP11 to drive Peg10 gene expression and activate lung epithelial cells. J Mol Cell Biol. 2018;10:60-73.

45. Kim S, Thaper D, Bidnur S, Toren P, Akamatsu S, Bishop JL, Colins C, Vahid S, Zoubeidi A. PEG10 is associated with treatment-induced neuroendocrine prostate cancer. J Mol Endocrinol. 2019;63:39-49.

46. Li B, Shi C, Li B, Zhao JM, Wang L. The effects of Curcumin on HCT-116 cells proliferation and apoptosis via the miR-491/PEG10 pathway. J Cell Biochem. 2018;119:3091-8.

47. Cichocki F, Wu CY, Zhang B, Felices M, Tesi B, Tuininga K, Dougherty P, Taras E, Hinderlie P, Blazar BR, et al. ARID5B regulates metabolic programming in human adaptive NK cells. J Exp Med. 2018:215:2379-95.

48. Ghofrani J, Lucar O, Dugan H, Reeves RK, Jost S. Semaphorin 7A modulates cytokine-induced memory-like responses by human natural killer cells. Eur J Immunol. 2019:49:1153-66.

49. Gamliel M, Goldman-Wohl D, Isaacson B, Gur C, Stein N, Yamin R, Berger M, Grunewald M, Keshet E, Rais $Y$, et al. Trained memory of human uterine NK cells enhances their function in subsequent pregnancies. Immunity. 2018:48: 951-62.

50. Levy J, Towers CG, Thorburn A. Targeting autophagy in cancer. Nat Rev Cancer. 2017:17:528-42.

\section{Publisher's Note}

Springer Nature remains neutral with regard to jurisdictional claims in published maps and institutional affiliations.

Ready to submit your research? Choose BMC and benefit from:

- fast, convenient online submission

- thorough peer review by experienced researchers in your field

- rapid publication on acceptance

- support for research data, including large and complex data types

- gold Open Access which fosters wider collaboration and increased citations

- maximum visibility for your research: over $100 \mathrm{M}$ website views per year

At $\mathrm{BMC}$, research is always in progress.

Learn more biomedcentral.com/submissions 